\title{
A Note on Money
}

In the course of his career Ibn Battuta received numerous gifts and salary payments in gold or silver coins. He usually refers to these coins as dinars, though sometimes distinguishing between "gold dinars" and "silver dinars." In the early Islamic centuries the weight of a gold dinar was set at 4.25 grams. In Ibn Battuta's time, however, the weight and fineness of both gold and silver coins, as well as the exchange rate between them, varied greatly from one period or country to the next. It would be futile, therefore, to express the value of money he received in terms of modern dollars or pounds sterling. In fourteenth-century India, where he was paid large sums from the public treasury, a "silver dinar" (or silver tanka) was valued at about one-tenth of a gold dinar. 